\section{B A Institute of \\ YK Business Administration \\ 六下 \\ Karachi \\ Leadership and Ideas for Tomorrow}

Business Review

Volume 3 Issue 2 July-December 2008

$7-1-2008$

\title{
Consolidation in Indian banking industry - need of the hour
}

\author{
Syed Ahsan Jamil \\ Institute of Productivity and Management, Lucknow, India \\ Bimal Jaiswal \\ University of Lucknow, Lucknow, India \\ Namita Nigam \\ Institute of Environment and Management, Lucknow, India
}

Follow this and additional works at: https://ir.iba.edu.pk/businessreview

Part of the Finance and Financial Management Commons

(c) $\underset{\mathrm{EY}}{\mathrm{i}}$

This work is licensed under a Creative Commons Attribution 4.0 International License.

\section{Recommended Citation}

Jamil, S. A., Jaiswal, B., \& Nigam, N. (2008). Consolidation in Indian banking industry - need of the hour. Business Review, 3(2), 1-16. Retrieved from https://doi.org/10.54784/1990-6587.1154

This article is brought to you by iRepository for open access under the Creative Commons Attribution 4.0 License and is available at https://ir.iba.edu.pk/businessreview/vol3/iss2/8. For more information, please contact irepository@iba.edu.pk. 


\title{
DISCUSSION
}

\section{Consolidation in Indian Banking Industry- Need of the Hour}

\author{
Syed Ahsan Jamil \\ Institute of Productivity and Management, Lucknow, India \\ Bimal Jaiswal \\ University of Lucknow, Lucknow, India \\ Namita Nigam \\ Institute of Environment and Management, Lucknow, India
}

\begin{abstract}
$\mathrm{T}$

his study is aimed at trying to unravel the fast and metamorphic changes been brought about within the Indian banking industry. With the government in India clearly specifying that it will liberalize the entry of foreign banks in India by 2009 alarm bells have started ringing for underperforming banks who largely nurtured under government protection and lack of competition. It is now a fight for survival. Consolidation seems to be the only viable solution for most of theses beleaguered banks.
\end{abstract}

Key words: consolidation, Mergers, Non-performing assets, Capital adequacy Ratio

\section{INTRODUCTION}

"The world goes up and the world goes down. And the sunshine follows the rain; And yesterday's sneer and yesterday's frown can never come over again. All things must change to something new, to something strange." Since India treaded on the path of liberalization, globalization and privatization, it ushered in a new phenomenon in the Indian Corporate World too - Corporate Restructuring. The last decade brought about 'sea of a change' in the corporate approach of how to do business. There was an awakening, from the common people to government, to top economic guru, towards the revamping of the entire spectrum of India's economic scenario. In fact last decade witnessed the greatest rush of merger and acquisition activity in the history of India's corporate sector post reform period. It is race for survival once again proving the Darwin's theory of - 'Survival of the fittest'.

The Indian Banking industry, one of the pillars of economic growth of the country also saw hectic activities to consolidate and restructure given the winds of changes every where. This paper is an attempt to showcase the imminent changes that are bound to bring metamorphic and far reaching changes in the Indian banking milieu. 


\section{INDIAN BANKING INDUSTRY}

Sound and effective banking system is the foundation for healthy economy. The most striking characteristic of Indian banking system is its extensive reach. It is no longer confined to only metropolitans or cosmopolitans in India. In fact it has reached even to the remotest corners of the country. They are one of the main pillars of Indian economy's growth process. The first bank in India was established in 1786. From 1786 till date, the journey of Indian banking system can be segregated in to three distinct phases.

\section{PHASE - I}

\section{From 1786 - 1969}

The general bank of India was set up in the year 1786. Next came, the bank Hindustan and Bengal bank. The EIC established Bank of Bengal (1809), Bank of Bombay (1840) and Bank of Madras (1843) as independent unit and called it presidency banks, which were later amalgamated in 1920 to form one bank.-Imperial bank of India. A numbers of other banks viz Allahabad bank, Punjab National Bank, Bank of India, Bank of Baroda; Canara Bank etc were also set up between 1865 and 1913.

During the first phase the growth was very slow and there were approximately 1100 banks, mostly small bank with limited reach. To streamline the functioning and activities of commercial banks, the government came up with the banking Regulation Act 1949 soon after independence.

\section{PHASE II}

Govt. took the major steps in banking sector reforms in 1955, it nationalized Imperial banks and formed State bank of India (SBI). Seven banks which were subsidiary of SBI were also nationalized in 1959-60 and in 1969, 14 major commercial banks in the country was also nationalized.

The following are the steps taken by the govt. to regulate banking institutions in the country.

\begin{tabular}{|l|l|l|}
\hline 1949 & $:$ & Enactment of Banks Regulation Act \\
\hline 1955 & $:$ & Nationalization of SBI \\
\hline 1959 & $:$ & Nationalization of SBI subsidiaries \\
\hline 1961 & $:$ & Insurance cover extend to deposits \\
\hline 1969 & $:$ & Nationalization of 14 commercial banks \\
\hline 1971 & $:$ & Creation of credit guarantee corporation \\
\hline 1975 & $:$ & Creation of Regional Rural banks (RRB) \\
\hline 1980 & $:$ & Nationalization of seven banks with deposits over 200 cores. \\
\hline
\end{tabular}




\section{PHASE III}

As the winds of liberalization started, in 1992 banking industry was also liberalized with the removal of entry barrier in Indian banking industry, which saw the emergence of private sector banks who gave a new glamorous look to the banking industry. The technological savvy, customer oriented services, innovative products have become the order of the day.

\section{CURRENT SCENARIO}

Today, the Indian banking industry is in transition phase. Public Sector banks which currently account for more than $78 \%$ of total assets are saddled with Non performing Assets (NPAs), falling revenues from traditional sources, lack of modern technology and a massive work force, while the new private sector banks are forging ahead and rewriting the traditional banking business model by way of their sheer innovation and service.

Foreign banks and the new private sector banks on an average are far more efficient than Public Sector banks. The average Return on assets (ROA) for 2005-06 was 1.52 and 0.97 for foreign and new private sector banks reported as against 0.86 for the SBI group and 0.81 for nationalized banks.

The private players however can not match the Public Sector banks great reach, great size and access to low cost deposits. Therefore one of the means for them to combat the PSBs has been through the merger and consolidation route.

The Indian banking industry comprises of many banks of various size, strengths and reach. As on March 05, there are around 100 scheduled commercial banks, four nonscheduled commercial banks and 196 Regional Rural banks. The SBI and its seven associate have around 14.000 branches, the 19 nationalized banks have 34.000 branches, the Regional Rural banks have around 14,700 branches and foreign banks around 225 branches.

If we include the branch network of old and new private banks, there are about 68,000 branches across the country and on an average one bank branch cater to 15,000 people only. Thus we can say that India is not only under banked but under serviced also. A country of 1.1 bn people has only 250 million account holders and that too having majority in metropolitan and urban cities.

On the global front, the banker's list of the top 1000 banks of the world (July 04) featured just 20 Indian banks only. In fact in the top 500 only six Indian banks featured and in the top 100 only one bank figured at the $82^{\text {nd }}$ position -State Bank of India. The combined assets of the five largest Indian banks - State Bank Of India 
(SBI), Industrial Credit and investment Corporation of India (ICICI), Punjab National Bank (PNB), Canara bank and Bank of India as in 2003, were less than the assets of largest Chinese bank, China Construction Bank, which is roughly 7.4 times the size of the SBI, which means that its ability to do business whether domestically or globally is significantly more than any one of our Indian banks.

SBI the biggest Indian bank having 100 million customers is very small in comparison to Citi bank, which has market capitalization of $\$ 25$ billion as against the SBI market capitalization of $\$ 7.5$ billion. Citi bank has a capital of $\$ 67$ billion and we have $10 \%$ of that only. Thus, it clearly shows that Indian banks lack global scale. The existence of too many banks results in the paradox of low profitability per customer for banks and higher pricing for customer.

Thus in the present scenario consolidation of banks is imperative $\&$ it is expected that, "consolidation in the banking space is likely to gather momentum in the coming year."

\section{CONSOLIDATION}

The meaning of the word consolidation is to strength, unite or combine. However the word is viewed differently by opposing parties. For one, it is a sense of becoming stronger and bigger with more power and for other a threat. The time has come to leave this aside and seek the true meaning of consolidation where the sum of whole is greater than the sum of parts.

"Consolidation" is the crying need of the Indian banking industry" According to SBI chairman Mr. A.K. Purwar speaking at the annual FICCI banking conference in Mumbai. He said, "Four to five large players must emerge like SBI and ICICI. We need to be able to expert our banking services to the outside world."

\section{MOTIVE BEHIND CONSOLIDATION}

1. Growth: One of fundamental motives behind the merger is impulsive growth; organizations that intend to expand need to choose between organic growth and acquisitive driven growth. Since the former is very slow, steady and relatively consumes more time than the latter is preferred by firms which are dynamic and ready to capitalize on opportunity.

2. Synergy: synergy is the phenomenon where $2+2=5$. i.e. the business combination is more profitable than the sum of the profits of the individual firms that were combined. It may be revenue enhancement or cost reduction. 
3. Strategic - the strategic reason could differ from case to case basis. For e.g. - if the two firms having complimentary business interest merges, this may result in consolidating their position in the market.

4. Market entry-it is a good way of entering in new markets.

5. Tax shields - the accumulated loss of the merged firm reduces the taxable profits of the acquirer.

\section{THE ASIAN EXPERIENCE OF CONSOLIDATION}

Banking consolidation came to the fore after the 1977 economic meltdown. Japan, which had seen a virtual collapse of its system, made consolidation its forte. The crises exposed the vulnerability of a weak-banking system to economic shocks. This resulted in the emergence of three banks - Mitsubishi UFJ, Mizuho and Sumitomo Mitsui. Today non-performing asset (NPA) level has come down to $2 \%$ from a peak of $8.4 \%$ in 2002. Hong-Kong too allowed complete FDI in banking and this facilitated the takeover of several banks by Singaporean and Taiwanese banks. In Indonesia, banks had capital adequacy ratio (CAR) below 25.7 were marked for immediate closure. Consolidation among banks was therefore resorted to, resulting in the number of the banks in Indonesia, which were 239 in 1996, to come down to 138 by 2003 .

In Malaysia, the regulator bank Negara has created ten anchor banks through the consolidation of 22 banks and 39 finance companies. Consolidation has resulted in the strengthening of the banking systems of these countries culminating into excellent customer serviceability and satisfaction. The overall benefit, more customers were attracted to the banking system.

\section{CONSOLIDATION IN INDIAN BANKING INDUSTRY}

M \& A is not new in the Indian banking industry. Years ago Imperial bank was formed by the amalgamation of the three presidency banks.

Historically barring a few instances, all M\&As in India have been part of crises management. They are forced by the regulator, the central Bank of India called Reserve Bank Of India (RBI) to protect depositor's money. To keep the public sector banking industry solvent, the RBI forced the merger of weak banks.

Few mergers among this category were taken place in Public Sector Banks in late 1960 and onwards to protect the interest of depositors of weak private banks like (Bank of Bihar with State Bank of India, 1969), Belgium Bank with Union Bank -1976.

In late 1990s, the merger of private bank have been for diverse reason like building up financial strength, capturing larger portion of the growing retail business and securing better regional presence. 
The first initiative was taken in November 1999, when HDFC \& Times bank shook hands. It is the first mergers in the history of Indian banking, signaling that Indian banking sector have also joined the M\&A bandwagon.

A few years later in 2002 successful merger of ICICI bank with bank of Madurai and Centurion bank with bank of Punjab (2005) created the new era in this subject matter. These mergers were market driven and not entirely for the reasons of the banking stability. It is expected that in the near future we will see the merger between even stronger Indian banks which is a clear deviation from the past where only weak banks were thrust upon the strong banks in the name of consolidation.

\section{NEED FOR CONSOLIDATION}

The Indian banks have less than three year to consolidate thus despite the stiff resistance consolidation holds the key to future growth due to the following:

1. Due to diversified operations and varying credit profiles of banks, mergers and consolidation would serve as a risk mitigation or risk sharing exercise as well as growth engine.

2. Only greater scale and size consolidation could only help save cost and improve operational efficiency as could be seen in Fig 1 for public sector banks, Fig 2 for private sector banks and Fig 3 for Foreign sector banks

Fig.1-PUBLIC SECTOR BANKS

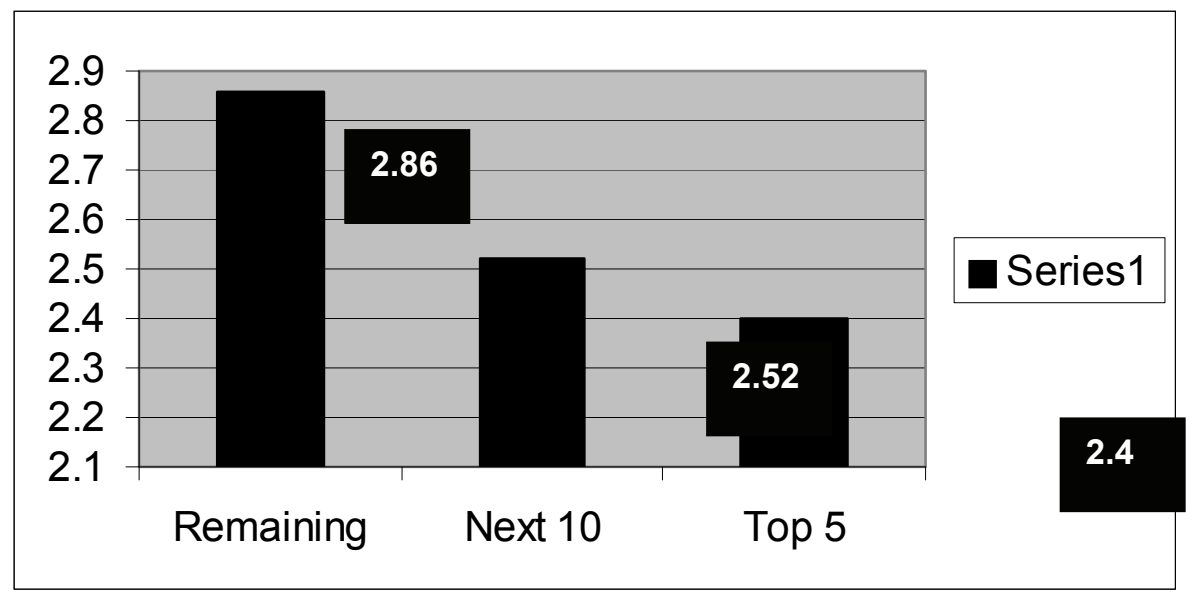

Operating cost / average assets 
Fig. 2-PRIVATE SECTOR BANK

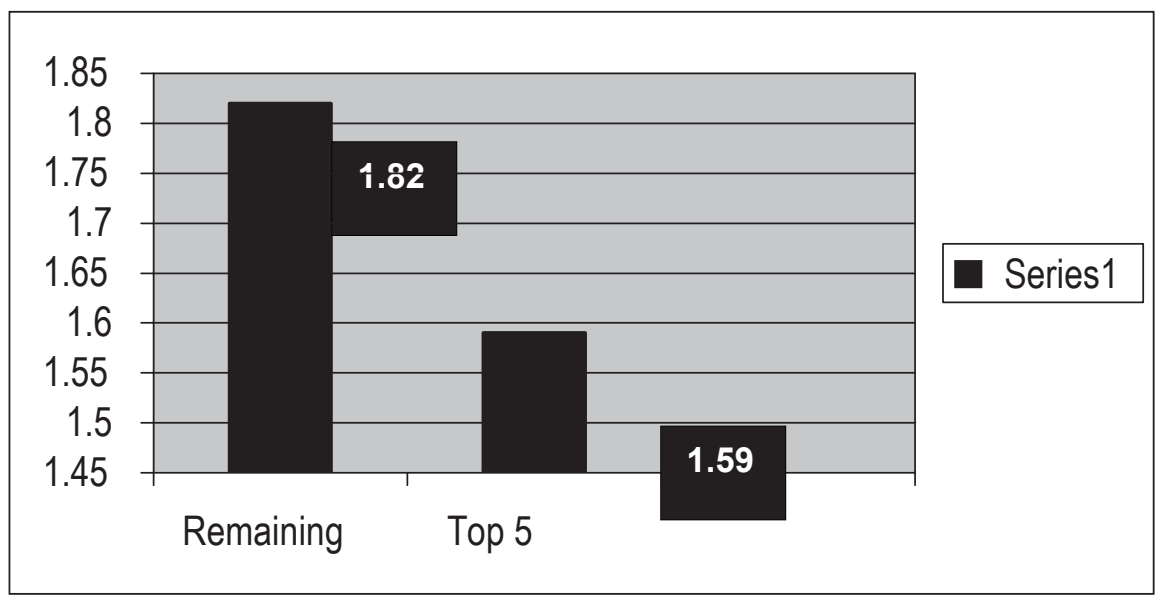

Operating cost / average assets

Fig. 3 -FOREIGN BANK

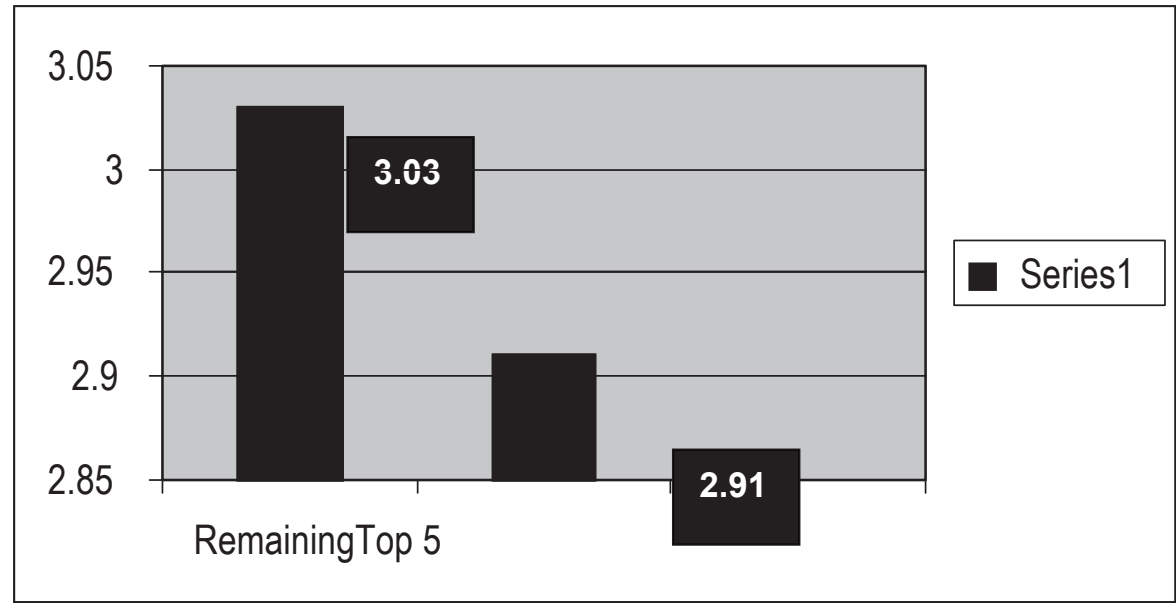

Operating cost / average assets

3. Banks will also have to explore different avenues for raising capital to meet norms under Basel II. According to Federation of Indian Chambers of commerce and industry (FICCI) of India survey, a majority of banks face an incremental capital requirement of $1-2 \%$ or more (exhibit II). It is estimated that the banking system will need an added capital infusion of 
around USD 9 million by March 2010. Consolidation is likely to be a best alternative to shore up their capital base.

\section{CAPITAL INCREMENT FOR BASAL II IMPLEMENTATION}

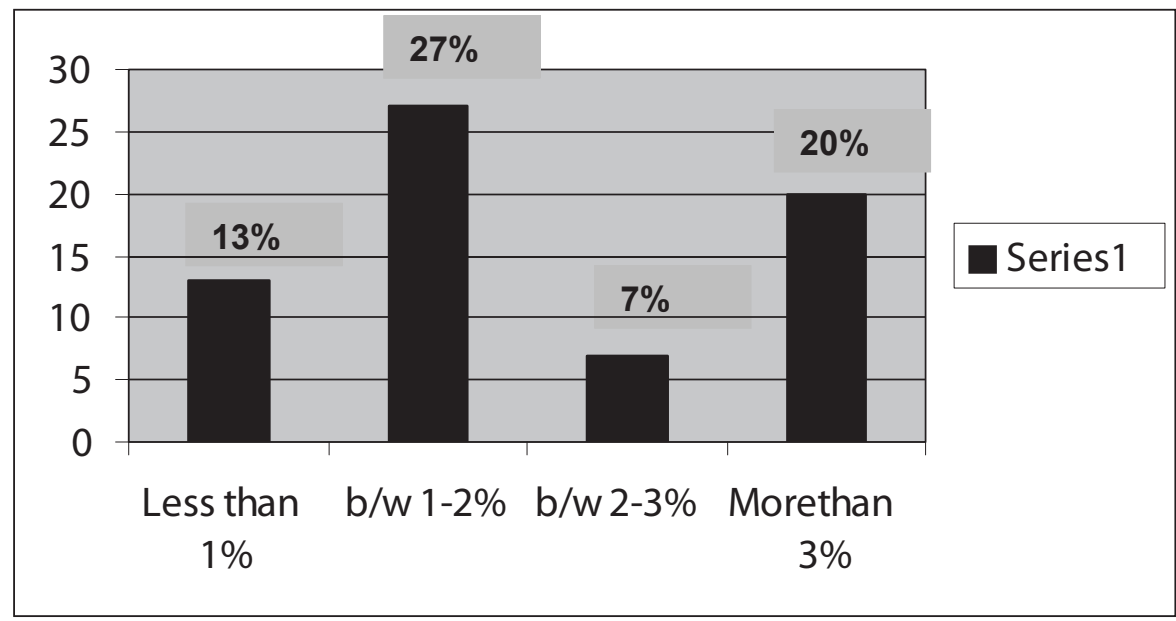

Source FICCI survey on preparedness of Indian banks for basal II

\section{EXHIBIT II}

4. To compete internationally, Indian banks have to achieve better net NPA ratios, better asset quality, returns on assets and better size. So consolidation in necessary.

\section{PROBLEMS INHERENT WITH CONSOLIDATION}

If the merger and acquisition are not backed with proper due diligence exercises keeping in mind the interest of the employees and the investor it success will always be questionable or in doubts. A proper well planned strategy could only ensure its success in the long run.

\section{PROBLEMS}

1. Merger deal turn out to be a poor deal due to unrealistic synergies or too high price paid for the deal (DBS-POS banks deal in 2000)

2. Sometimes banks are not able to manage post merger issues such as customer losses (bank one lost 2 Lac customer account while integrating first Chicago in 2000), poor management communication, handing of increased size.

3. Integration might get very difficult due to cultural issues. 
For example: Bank merger of DBS and Deo Hing, Citi bank and Travelers Groups etc have not really created shareholder value, mainly due to cultural issues.

In India the major merger that took place in the past were to rehabilitate the weak bank and for preserving banking stability. Forced $\mathrm{M} \& \mathrm{~A}$ as a total for rescuing ailing banks besides protecting public and depositor confidence was the strategy flowed by Indian banking industry. Some prominent merger among this category are merger of Banaras State Bank with Bank of Baroda (2002), Nedungadi Bank with Punjab National Bank (2003), Global Trust Bank with Oriental Bank of Commerce, united western bank with Industrial Development Bank India etc. most of these merger are not market driven but are the result of desperate situations faced by the central bank for reassuring the Indian investors.

In the recent times, private banks have seen voluntary $\mathrm{M} \& \mathrm{~A}$ activity, which is purely market driven. The merger of Times bank with Housing Development Finance Corporation (HDFC) was the first in that category. Later on the merger of the bank of Madurai with ICICI bank, reverse merger of ICICI with ICICI bank along with merger of centurion bank with bank of Punjab followed the same strategy.

Given below are some of the case studies of Mergers \& Acquisition in India

Merger of IDBI with United Western Bank

\begin{tabular}{|c|c|c|c|}
\hline & \multicolumn{2}{|c|}{ Post merger scenario } & Significance \\
\hline & Benefits of merger & Key challenges & \\
\hline $\begin{array}{l}\text { 1. } \begin{array}{r}\text { Before } \\
\text { merger }\end{array} \text { United } \\
\text { Western Bank } \\
\text { with poor asset } \\
\text { quality and } \\
\text { detoriating } \\
\text { financial } \\
\text { position was } \\
\text { having a gloomy } \\
\text { picture of its } \\
\text { future. } \\
2 . \text { The IDBI } \\
\text { with the B/S } \\
\text { size of Rs. } \\
81700 \text { cores had } \\
\text { a network of } \\
181 \text { branches }\end{array}$ & $\begin{array}{l}\text { (i) Merger gave } \\
\text { IDBI immediate } \\
\text { access to the } 230 \\
\text { branch network } \\
\text { of United } \\
\text { Western Bank, } \\
\text { thereby widening } \\
\text { its deposit } \\
\text { franchise. The } \\
\text { merger gave the } \\
\text { IDBI access to a } \\
\text { ready physical } \\
\text { infrastructure, } \\
\text { enabling it to } \\
\text { mobilize low } \\
\text { cost funds in that } \\
\text { time where RBI }\end{array}$ & $\begin{array}{l}\text { 1. A purchase } \\
\text { consideration was } \\
\text { just } 150 \text { cores but } \\
\text { there is hidden } \\
\text { cost of around Rs. } \\
100 \text { cores in the } \\
\text { form of bad loans. } \\
2 . \text { NPA of IDBI } \\
\text { increases to } 1.4 \% \\
\text { from } 1 \% \text { before } \\
\text { merger. } \\
3 . \text { UWB had an } \\
\text { employee base of } \\
\text { over } 3200 \text {, which } \\
\text { is } 70 \% \text { of IDBI. } \\
\text { Total strength. }\end{array}$ & $\begin{array}{l}\text { Despite the } \\
\text { various key } \\
\text { challenges, the } \\
\text { down ward risk } \\
\text { associated with } \\
\text { the merger } \\
\text { appears } \\
\text { minimum } \\
\text { making IDBI } \\
\text { stock attractive } \\
\text { as a long-term } \\
\text { proposition. }\end{array}$ \\
\hline
\end{tabular}




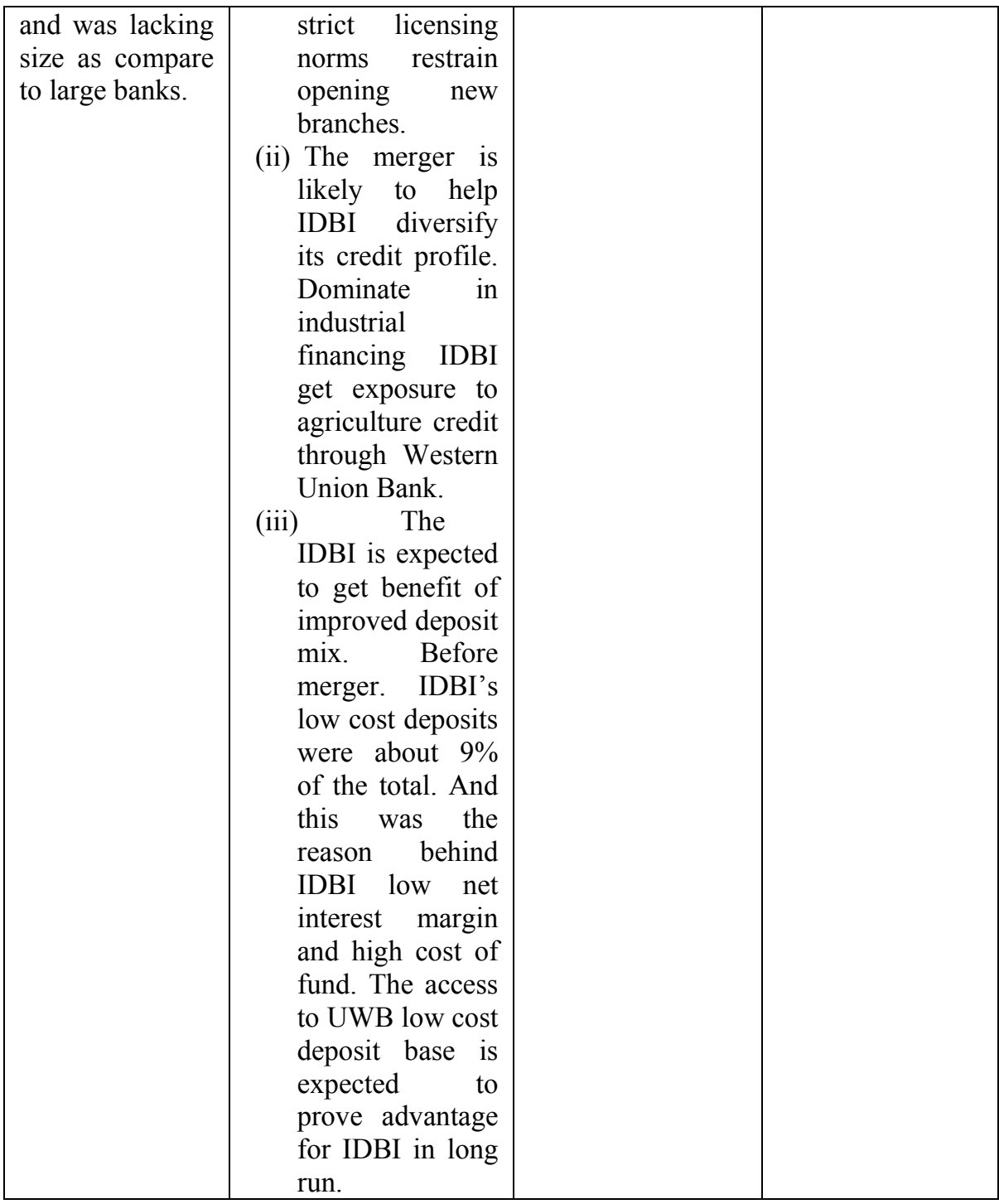

Merger of HDFC bank and Time bank

\begin{tabular}{|c|c|c|c|}
\hline \multirow{2}{*}{$\begin{array}{c}\text { Pre merger } \\
\text { scenario }\end{array}$} & \multicolumn{2}{|c|}{ Post merger scenario } & \multirow[t]{2}{*}{ Significance } \\
\hline & Benefits of merger & Key challenges & \\
\hline $\begin{array}{ll}\text { HDFC } & \text { bank } \\
\text { started in } 1994\end{array}$ & $\begin{array}{l}\text { 1. Post } \\
\text { HDFC }\end{array}$ & $\begin{array}{l}\text { 1. To integrate the } \\
\text { retail side of two }\end{array}$ & $\begin{array}{lr}\text { The } & \text { merger add } \\
\text { a } & \text { significant }\end{array}$ \\
\hline
\end{tabular}




\begin{tabular}{|c|c|c|c|}
\hline $\begin{array}{l}\text { has grown its } \\
\text { small asset base } \\
\text { of Rs. } 9 \text { bn } \\
(1995-96), \quad \text { to } \\
\text { over Rs. } 116 \text { bn } \\
\text { as on march } 2000 \\
\text { with } \\
\text { compounded } \\
\text { annual growth } \\
\text { rate of } 90 \% \text { and } \\
\text { total of } 115 \\
\text { braches in India } \\
\text { of which were } \\
\text { rural branches. }\end{array}$ & $\begin{array}{l}\text { emerged as the } \\
\text { largest private } \\
\text { sector bank in India. } \\
2 . \text { The new entity } \\
\text { has customer base } \\
\text { of 6, 50,000 to } \\
\text { serve. With average } \\
\text { HDFC bank's total } \\
\text { deposit touched Rs. } \\
6900 \text { cores and the } \\
\text { size of balance sheet } \\
\text { crossed massive } \\
9,000 \text { core market. } \\
3 \text { Bank not only } \\
\text { gained from the } \\
\text { existing } \\
\text { infrastructure but } \\
\text { also from the } \\
\text { employee work } \\
\text { culture. } \\
4 . \quad \text { Merger also } \\
\text { brought product } \\
\text { harmonization as } \\
\text { HDFC had the visa } \\
\text { network and Times } \\
\text { bank had master } \\
\text { card network. } \\
5 . \\
\text { advantage is the } \\
\text { expansion of branch } \\
\text { network as well as } \\
\text { geographical } \\
\text { coverage as HDFC } \\
\text { has } 65 \% \text { branches in } \\
\text { metros while Times } \\
\text { bank has only } 43 \% \\
\text { urban branches and } \\
\text { rest is rural areas. }\end{array}$ & $\begin{array}{l}\text { banks was difficult } \\
\text { as both the banks } \\
\text { had independent } \\
\text { proprietary system } \\
\text { for retail banking. } \\
\text { 2. Since all the } 650 \\
\text { employees from } \\
\text { Times bank had } \\
\text { been absorbed thus } \\
\text { the rationalization } \\
\text { of culture as early } \\
\text { as possible was the } \\
\text { challenge before } \\
\text { the management. }\end{array}$ & $\begin{array}{l}\text { value to the bank } \\
\text { in terms of } \\
\text { increase branch } \\
\text { network, } \\
\text { expanded } \\
\text { geographic } \\
\text { reach, enhanced } \\
\text { customer base } \\
\text { skilled } \\
\text { manpower, the } \\
\text { opportunity to } \\
\text { cross sell and } \\
\text { leverage } \\
\text { alternative } \\
\text { delivery } \\
\text { channels. }\end{array}$ \\
\hline \multicolumn{4}{|c|}{ ICICI bank with Bank of Madurai } \\
\hline $\begin{array}{c}\text { Pre merger } \\
\text { scenario }\end{array}$ & \multicolumn{2}{|c|}{ Post merger scenario } & Significance \\
\hline
\end{tabular}




\begin{tabular}{|c|c|c|c|}
\hline $\begin{array}{l}\text { As on march } 31 \text {, } \\
2000 \text {, ICICI bank } \\
\text { one of the largest } \\
\text { financial } \\
\text { institution had a } \\
\text { network of } 81 \\
\text { branches, } \\
\text { extension } \\
\text { counters and } 175 \\
\text { ATMs. The CAR } \\
\text { was at 19.64\% of } \\
\text { risk-weighted } \\
\text { asset, a significant } \\
\text { excess of } 9 \% \text { over } \\
\text { RBI's benchmark } \\
\text { and had an assets } \\
\text { base of Rs. } 582 \\
\text { bn. } \\
2 \text { Pre merge } \\
\text { BOM had an } \\
\text { attractive business } \\
\text { lemployee figure } \\
\text { of Rs. 202 lac, a } \\
\text { better in } \\
\text { technological } \\
\text { edge and had a } \\
\text { vast base } \\
\text { southern India } \\
\text { having } \\
\text { branches with } 82 \\
\text { of them in rural } \\
\text { areas. }\end{array}$ & $\begin{array}{l}\text { 1. The } \\
\text { amalgamation } \\
\text { enable then to have } \\
\text { a stronger financial } \\
\text { and operational } \\
\text { structure, which is } \\
\text { suppose to be } \\
\text { capable of greater } \\
\text { resource /deposits } \\
\text { mobilization. } \\
\text { 2. The ICICI branch } \\
\text { network not only } \\
\text { increased by 264 } \\
\text { but also increases } \\
\text { geographical } \\
\text { coverage as well as } \\
\text { convenience to its } \\
\text { customers. } \\
\text { 3. The merger } \\
\text { enables ICICI to } \\
\text { provide ATMs, } \\
\text { Phone and the } \\
\text { Internet banking and } \\
\text { financial services } \\
\text { and products to a } \\
\text { large customer base, } \\
\text { with expected } \\
\text { saving in cost and } \\
\text { operating expenses. } \\
\text { 4. The ICICI bank is } \\
\text { now enable to focus } \\
\text { on micro-finance } \\
\text { activities through } \\
\text { self-help group in } \\
\text { its priority sector } \\
\text { initiatives through } \\
\text { its acquired } 87 \text { rural } \\
\text { and 88 semi rural } \\
\text { branches. }\end{array}$ & 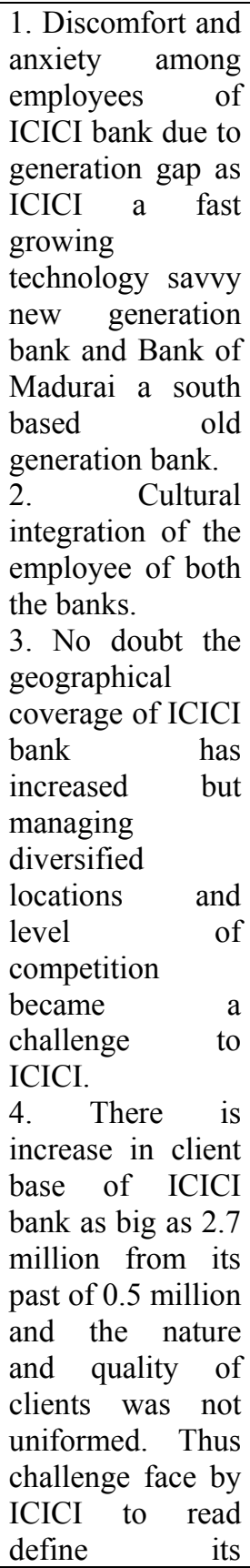 & $\begin{array}{l}\text { 1. The merger } \\
\text { has given ICICI } \\
\text { bank a hold on } \\
\text { south Indian } \\
\text { market which has } \\
\text { high rate of } \\
\text { economic } \\
\text { development. }\end{array}$ \\
\hline
\end{tabular}


Business Review - Volume 3 Number 2

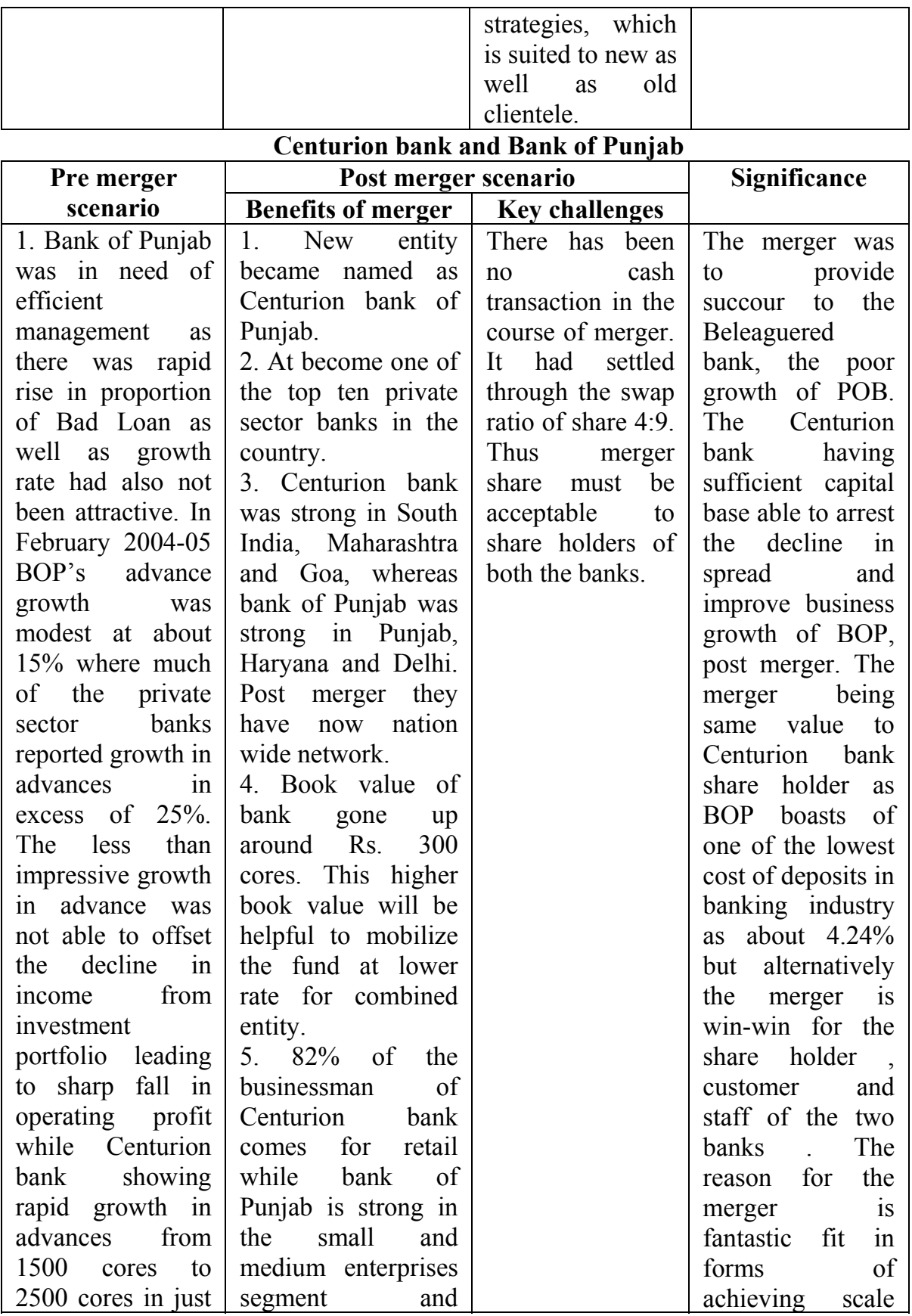




\begin{tabular}{|l|l|l|l|}
\hline 15 months since & agricultural sector. \\
end of the march & $\begin{array}{l}\text { Merger profit } \\
\text { diversity in } \\
2004 .\end{array}$ & $\begin{array}{l}\text { and geographical } \\
\text { presence. }\end{array}$ \\
2. Centurion bank & $\begin{array}{l}\text { operational activity } \\
\text { and combined bank }\end{array}$ & \\
has a strong & is full service \\
presence in the & is bank \\
west and the & commercial bor bence \\
south, the BOP & with strong presence \\
has a strong & in the retail, SME \\
presence in the & and agricultural \\
north. & segment. & \\
\hline
\end{tabular}

\section{FUTURE MERGER POSSIBILITIES}

Indian banking industry is likely seen many more merger in the coming future.

The government has been mulling with the idea of merger of two PSB -Union Bank of India and Bank of Baroda. The new entity - Union Bank of India and Bank of Baroda will have an assets base on over Rs. 1,43,175 or and will become second largest commercial bank, overtaking ICICI (Rs. 125229 or), the largest being the State Bank of India (Rs. 4,07, 815 or).

Ideally State Bank of India should merge its seven associate banks with itself. If there is merger of three big Indian banks - Punjab National Bank, Canara Bank and Bank of Baroda, the combine entity will be having as asset base of Rs. 6,51,588 or and branch network of over 17000 . With this asset, it will emerge as formidable force in Asia out side Japan.

If there could be a merger of Punjab National Bank and Bank of Baroda; the merged entity would be catapulted in to big league with Rs. 1, 87,437 cores asset base and 7,714 strong branch networks.

Other mergers that could lie on the horizon may be of relatively smaller banks like Vijay Bank and Allahabad bank, Punjab and Sindh bank, Dena Bank and United bank of India or Karur Vysya, City Union and Federal Bank etc.

\section{CONCLUSION}

Presently Indian banking industry is growing by $15-17 \%$ annually as compare to 1$2 \%$ growth rate of European bank. So enormous opportunities exist and industry needs to serve million of people who are out of the banking network. 
In the year 2009, the government of India will lift severe restriction on the entry of foreign bank thus giving them all freedom to open branches acquire competitors and plan for the growth that till now are only enjoyed by their domestic counter parts. Therefore it is an open secret that Indian domestic banks whether public or private have time till 2009 to set their house in order or face tough competition from these big and fiercely competitive foreign banks. It seems that the only solution that lies with most of the Indian banks in order to save them from these predators is to tread the path of consolidation and synergies with respect to their reach, innovative products and excellent customer facilities.

Thus post April 2009, the banking scenario is expected to change dramatically and bank consolidation assumes significance from the point of view of making Indian banking system stronger and sound with rapid growth leading to sustainable development of the Indian Economy.

\section{REFERENCES}

The merger mantra, Sridhar V., Frontline, Vol. 21, Oct 2004.

Justin Paul "Strategic Management of Merger Decision and swap Ratio valuation." A case study of Bank of Madurai with ICICI Bank, IBA Bulletin Special Issue 2003.

Indian Banking Association Report on Banking, Vision 2010, 2003

Merger and Acquisition for consolidation in Indian Banking Industry; The Success Mantra, Dr.K.Mohan, Management Trends Vol.3 No.1 2005-06.

Marriage Season: Who will tie the knot, Business Standard, Banking Annual 2006.

Radhi Kamath, IDBI-United Western Bank Merger- A Case Study, IBA Bulletin.

A. Vasudevan, Survey on the Merger scene in the Banking Sector.

IBA Bulletin Special Issue on consolidation in Indian Banking Industry

M\&A, January 2005, Vol. XXVII

RBI Bulletin, Various Issues.

www.google.com

www.rbi.org 


\section{ADAPTIVE VS. UNADAPTIVE CORPORATE CULTURES}

\begin{tabular}{|c|c|c|}
\hline & $\begin{array}{l}\text { Adaptive Corporate } \\
\text { Cultures }\end{array}$ & $\begin{array}{l}\text { Unadaptive Corporate } \\
\text { Cultures }\end{array}$ \\
\hline Core Values & $\begin{array}{l}\text { Most managers care } \\
\text { deeply about customers, } \\
\text { stockholders, and } \\
\text { employees. They also } \\
\text { strongly value people } \\
\text { and processes that } \\
\text { can create useful } \\
\text { change (e.g., leadership } \\
\text { up and down the } \\
\text { management hierarchy) }\end{array}$ & $\begin{array}{l}\text { Most managers care } \\
\text { mainly about themselves, } \\
\text { their immediate work } \\
\text { group, or some product } \\
\text { (or technology) } \\
\text { associated with that } \\
\text { work group. They value } \\
\text { the orderly and risk } \\
\text { reducing management } \\
\text { process much more } \\
\text { highly than leadership } \\
\text { initiatives }\end{array}$ \\
\hline $\begin{array}{l}\text { Common } \\
\text { Behavior }\end{array}$ & $\begin{array}{l}\text { Managers pay close } \\
\text { attention to all } \\
\text { their constituencies, } \\
\text { especially customers, } \\
\text { and initiate change } \\
\text { when needed to serve } \\
\text { their legitimate } \\
\text { interests, even if } \\
\text { that entails taking } \\
\text { some risks }\end{array}$ & $\begin{array}{l}\text { Managers tend to behave } \\
\text { somewhat insularly, } \\
\text { politically, and } \\
\text { bureaucratically. } \\
\text { As a result, they do } \\
\text { not change their } \\
\text { strategies quickly } \\
\text { to adjust to or take } \\
\text { advantage of changes } \\
\text { in their business } \\
\text { environments }\end{array}$ \\
\hline
\end{tabular}

Corporate Culture and Performance: John P. Kotter and James L. Heskett, p. 51 